JoAnNa MaLESZYŃSKA

Uniwersytet im. Adama Mickiewicza w Poznaniu

\title{
Robinsonada na scenie albo dzieje nieudanej adaptacji
}

Nigdy smutne przygody młodego awanturnika nie
zaczęly się tak nagle i nie trwały tak długo.

(Defoe 10)

Gdy Jacques Offenbach komponował operę pod tytułem Robinson Crusoe, był już bardzo popularnym wśród publiczności i uznanym przez krytyków autorem muzycznych dzieł scenicznych. Wśród dziesięciu stworzonych wcześniej utworów znajdziemy już nieco dziś zapomniane, jak błazenada muzyczna $D w a j$ ślepcy (Les deux avengles, 1855), czy „muzyczną chińszczyznę” pod tytułem Ta-ki-kram (Ba-ta-clan, 1856); znajdziemy też często wystawiane i nagrywane na płyty klasyczne opery komiczne: Orfeusz w piekle (Orphee aux Enfers, 1858), Piękna Helena (La Belle Helene, 1864) czy Życie paryskie (La vie parisienne, 1866) (Kamiński 1: 5-39). Słynne tytuły tych dzieł mówią coś nawet tym osobom, które $\mathrm{z}$ teatrem muzycznym są na bakier.

Kiedy więc w listopadowy wieczór 1867 roku wystawiano po raz pierwszy Robinsona Crusoe, elegancka i ta całkiem zwyczajna publiczność Opera-Comique mogła się spodziewać porywającego spektaklu, wypełnionego dynamiczną akcją i ozdobionego melodyjnymi ariami i oszałamiającymi partiami baletowymi. Cały Paryż nucił wtedy przecież arię Parysa W lasku Ida trzy boginie czy galop „Ach, ach, jedź już na Kretę, jedź już na Kretę, jedź już na Kretę" z La Belle Helene; wszyscy też znali brawurowego kankana z Orphee aux Enfers i często podrygiwali w jego rytm. Uwielbiane spektakle wystawiano bowiem, nie tylko w Paryżu, dosłownie setki razy. Szczególnie te dwie opery, których libretta oparte zostały o monumentalne mity greckie "przerobione” w satyryczny sposób, a których premiery 
wywołały „prawdziwy skandal erotyczno-polityczny” (Kamiński 1: 26), rozbudziły apetyty francuskiej publiczności. Spodziewano się przedstawienia, które - jak poprzednie dzieła kompozytora - będzie wydarzeniem nie tylko artystycznym, ale i obyczajowym. Przecież, jak pisał biograf Offenbacha, „lato 1867 roku przyniosło apogeum jego panowania nad światowym repertuarem” (cyt. za: Kamiński 1:36).

Libretto do opery Robinson Crusoe autorstwa Eugene'a Cormona i Hectora Cremieux było przeróbką sławnej powieści Daniela Defoe; nie dowierzając jego nośności scenicznej, libreciści odnieśli się także do popularnej pantomimy brytyjskiej pod tym samym tytułem, będącej - co oczywiste - satyryczną przeróbką arcydzieła mistrza prozy z Londynu. Niestety, tym razem ani jeden z trzech aktów liczącego cztery godziny dzieła nie zachwycił paryżan: spektakl zszedł $\mathrm{z}$ afisza po kilku zaledwie przedstawieniach z powodu braku zainteresowania publiczności. Okazał się klapą i komercyjną, i artystyczną.

Na pytanie, dlaczego tak się stało, historycy gatunku nie odpowiadają jednoznacznie. Czy zabrakło chwytliwych melodii, jakiegoś choćby jednego „przeboju” do zapamiętania po tym, jak już opadnie kurtyna? Może to nieciekawe inscenizacje - a wystawiano Robinsona Crusoe do lat dziewięćdziesiątych xx wieku około czterdzieści razy - zasłoniły urodę dzieła? A może jednak „zawiniło” libretto: tekst sceniczny, monologi, dialogi, arie i recytatywy nie zostały dostosowane do zadań dramatycznej akcji, zbyt daleko odbiegając od powszechnie znanego pierwowzoru?

Offenbachowska robinsonada jest doskonałym potwierdzeniem tezy o stopniowym i konsekwentnym jednocześnie oddalaniu się adaptacji od tekstu pierwotnego. Z punktu widzenia literaturoznawcy adaptacja między innymi prozy na potrzeby teatru, na przykład muzycznego, wydaje się procesem naturalnym, wręcz koniecznym. Jerzy Ziomek nazywał przedmiot swoich badań - literaturę wprost „twórczością niesuwerenną”. W Powinowactwach literatury dowodził, że współżycie różnych sztuk i form społecznej świadomości jest oczywistym sposobem wiecznego „istnienia przez przekształcanie” epiki, liryki i dramatu (Ziomek 355 i nast.). Badaczka libretta Elżbieta Nowicka zwróciła zaś uwagę na otwartość teatru muzycznego wobec traktowanych jako inspiracja kulturowych tematów i wątków, wywodzonych zawsze z literatury: „W wielkim, operowym «theatrum mundi» prezentowane były działania władców i pokojówek, a aktywistyczny wigor historii splatał się z kontemplacyjnym wymiarem mitu i namysłem nad pojedynczą egzystencją" (Nowicka 9).

A odnosząc się do Offenbachowskich czasów, dodaje:

Wiek dziewiętnasty nie cechował się co prawda pod tym względem jakąś zasadniczą odmiennością na tle innych stuleci, nie oznacza to 
jednak, by nie odcisnął swojego wyraźnego znaku. W operze tego stulecia zapisały się bodaj wszystkie ważne i zajmujące człowieka kwestie, a ona sama towarzyszyła ludziom, jeśli można wnosić o tym na podstawie wielu powieściowych fabuł, $\mathrm{w}$ decydujących momentach życia (Nowicka 9-10).

Trzyaktowa „komedia sceniczna” opowiada bardzo skróconą, „uwyraźnioną", by tak rzec, scenicznie historię tytułowego bohatera. Cormon ${ }^{1}$ i Cremieux ścieśnili czas akcji, zamykając go w siedmiu latach; miejscem operowego dziania się uczynili najpierw rodzinny dom bohatera, mieszczący się z pewnością w mieście portowym - w Yorku, Hull lub Bristolu (akt I), potem przenieśli akcję na bezimienną wyspę bezludną, zatem pominięty został wątek podróży morskiej, burzy i przygód, które spotkały bohatera w ciągu kolejnych sześciu lat; jego spokojne życie w towarzystwie jedynie „dzikiego sługi” Piętaszka zostanie zakłócone przez przybycie ekspedycji ratunkowej (akt II); perypetie miłosne pomiędzy zakochaną Edwige a mało spostrzegawczym Robinsonem z udziałem oczarowanego Edwige Piętaszka (który jako czarnoskóry i dziki nie ma u niej oczywiście żadnych szans, a jego wzdychania mają li tylko komiczny charakter), przeplecione straszno-śmiesznym wątkiem spotkania kanibali oraz groźnych, ale w końcu pomocnych piratów, wypełniają i wieńczą szczęśliwym finałem całe przedstawienie (akt III).

Autorzy libretta rozpisali fabułę i role w niej na dziewięć osób, wchodzących z sobą w różnorakie relacje. Są to, oprócz bohatera tytułowego: jego ojciec, sir William Crusoe, oraz matka, Lady Deborah; Edwige - kuzynka, z czasem narzeczona, w finale zaś małżonka Robinsona; jej pokojówka Susanne ze swym chłopakiem Tobym, oczywiście także służącym; Piętaszek; Jim Cocks - marynarz, rozbitek i z konieczności „kucharz” plemienia kanibali; Will Atkins groźny zbójca, herszt piratów a w końcu kapitan, wiążący Robinsona i Edwige ślubnym węztem przysięgi.

W ujęciu tria Cormon - Cremieux - Offenbach Robinson jest jak syn marnotrawny, który nieświadomie respektując prawa życia, prawo syna i reguły rozwoju i dojrzewania emocjonalnego oraz społecznego, wyrusza w świat po naukę, która przyprowadzi go, zmienionego doświadczeniem, z powrotem, do domu. Może nie jest nałogowym hulaką, ale jest z pewnością włóczykijem, którego „ciągnie w świat”. Ojciec czyta zresztą znaną przypowieść z Ewangelii według świętego Łukasza żonie i siostrzenicy w oczekiwaniu na powrót zau-

1 Pod tym pseudonimem ukrywał się popularny autor sztuk Pierre-Etienne Piestre (Kamiński 36). 
roczonego podróżowaniem syna-hultaja². Operowy Robinson w pierwszym akcie do domu powraca, ale tylko po to, by wyruszyć w kolejną, jeszcze dalszą podróż. Podczas gdy dotąd pływał do nieodległych portów, teraz uda się w rejs do Ameryki Południowej. I nic go nie powstrzyma - ani błagania ojca, ani łzy matki, ani miłosne zaklęcia wiernej Edwige.

Ponieważ drugi akt byłby nieznośnie statyczny z powodu obecności na scenie tylko dwu postaci, Robinsona i przygarniętego przez niego właśnie Piętaszka, w dodatku do pewnego momentu niemego, na odsiecz pozostającego już kilka lat na wyspie bohatera przybywa, wolą autorów, Edwige z Suzanne i Tobym. Wpadają oni niemal natychmiast w ręce kanibali, a Jim Cocks ma $\mathrm{z}$ nich ugotować wieczorny posiłek dla całego plemienia. W Edwige „dzicy” rozpoznają jednak nagle jasnowłosą, oczekiwaną od wieków boginię i rezygnują z posiłku na rzecz... złożenia jej w ofierze bożkowi Saransze. Strzały zauroczonego „białą panią" Piętaszka ratują życie dziewczynie.

Do wyspy tymczasem przypływają żądni wszelkich łupów piraci. To ich okręt za pomocą fortelu przejmują nasi bohaterowie, a potem ratują go z rąk kanibali, by razem wypłynąć wreszcie w stronę dalekiej Anglii.

Z tego bardzo skrótowego streszczenia wynika, że związek operowego libretta z literackim pierwowzorem jest co najwyżej powierzchowny. Wspólne są: dwie główne postaci - Robinson i Piętaszek; odejście bohatera z domu, ucieczka na morze i pobyt na bezludnej wyspie; „adopcja” Piętaszka i opowieść o uratowaniu go z rąk ludożerców; powrót Robinsona do ojczyzny. Wszystkie pozostałe elementy składowe dzieła: bohaterowie, przedstawione w formie scenicznego „actio” wydarzenia, komediowe skupienie wyłącznie na stworzeniu perypetii, potraktowanie ról poszczególnych aktorów przedsięwzięcia i ich interakcji - są, by tak rzec, pretekstowe. Przywołane i użyte zostają po to, by opowiedzieć zaciekawiającą, zabawną a przede wszystkim egzotyczną historyjkę. Gdyby główny bohater nosił inne imię, nikt z widzów nie zwróciłby na to uwagi; nie odczułby znaczącej różnicy w odbiorze dzieła. Wspomniana pantomima brytyjska, będąca źródłem natchnień dla autorów libretta, była kpiną - nie z arcydzieła Daniela Defoe, ale z... obowiązującej w ówczesnym czasie operowej mody na egzotykę! Offenbach i jego libreciści wyraźnie nawiązywali do wystawianej od 1865 roku "grand opera” - Afrykanki autorstwa gwiazdy ówczesnych scen operowych, Giacomo Meyerbeera. Eugene Scribe, który napisał libretto do melodramatycznego dzieła, skupił się w nim na miłosnych przygodach bohaterów; jest wśród nich sam Vasco da Gama,

2 O tej paraboli jako „narracji moralnej” pisałam w artykule: Biblijna przypowieść o synu marnotrawnym i jej literackie transpozycje (Maleszyńska). 
słynny odkrywca, jego narzeczona Ines, para niewolników: Selika i Nelusko oraz podstępny Don Pedro. Nagłe zwroty akcji i poplątane relacje uczuciowe między przybyszami a „dzikimi tubylcami”, jak pisze badacz, „zjadły Historię” (Kamiński 1: 958). I już nieważne było, czy prawdziwy Vasco da Gama przybył do tych właśnie brzegów, co odkrył i czym (bezprawnie) zawładnął. Istotne stało się poświęcenie tytułowej Afrykanki - Seliki dla ukochanego i niedostępnego żeglarza, i jej finałowa, samobójcza śmierć pod trującym drzewem. Ta popularna opera stała się z czasem symbolem niedorzeczności librettowej akcji, w której liczył się tylko - jakikolwiek! - pretekst do emocjonalnego śpiewania. W Afrykance swoisty nadmiar perypetii, przenoszenie uczuć z jednej amantki na drugą i niespotykana rola przypadku nie uwiarygadniały postaci, przeciwnie - często nadawały poszczególnym, przeładowanym scenom cechy karykaturalne. Poważny dramat zmieniał się, mimo woli twórców, w autoparodię. Nie trzeba chyba dodawać, że Afrykanka nie zagościła na stałe w repertuarze scen operowych xx wieku, a obecnie nie grywa się jej wcale.

W świetle tych porównań Robinson Crusoe Offenbacha jawi się jako dzieło mimo że chybione - to jednak mądrzejsze i bardziej ironiczne niż gatunek „opera comique”, w której chodzi tylko o miłą dla ucha muzykę, charakterystyczne, przerysowane postaci (typy) i dobry żart. Przecież jest to dzieło samoświadome, a wątek gatunkowo-autotematyczny pojawia się tu nie tylko w odniesieniu do guru ówczesnej sceny operowej - Meyerbeera - ale także wobec od stosunkowo niedawna obecnych w uszach i wyobraźni widzów pomysłów wielkiego reformatora tejże sceny, Ryszarda Wagnera:

Drugi cel satyry to oczywiście wagnerowska „opera przyszłości”, czego wcieleniem jest kucharz Jim Cocks, krzewiący postępową sztukę wśród dzikusów. Choć historyjka jest zwariowana, natchnienie Offenbacha nigdy nie słabnie [...] (Kamiński 2: 36).

Łatwo się domyślić, że te wzajemne odniesienia i filiacje z czasem zupełnie się zatarły, a dla współczesnych widzów byłyby całkiem nieczytelne.

Operowa dziewiętnastowieczna wersja przygód Robinsona Crusoe okazuje się od literackiego pierwowzoru jeszcze dalsza, niż się dotąd wydawało; służyła innym niż powieść celom, wyznaczała odmienny, o wiele krótszy i bliższy niż w literackim tekście horyzont wartości. Adaptujący przypadki Robinsona na potrzeby muzycznej sceny libreciści zajmowali się, zdaje się, prawie wyłącznie skreślaniem dużych jego fragmentów. To zrozumiałe w procesie adaptacji, jednak rozmiar ingerencji w tym przypadku przekracza normę rozpoznawalności: zwyczajnie zaciera ślady powiązań nowo powstałego 
utworu ze źródłem i likwiduje znaki szczególne, które uczyniły z powieści Daniela Defoe arcydzieło.

Pisząc o adaptacji literatury na potrzeby opery, Iwona Puchalska zwraca uwagę, że - szczególnie wobec dzieła pierwotnie niescenicznego, jak powieść czy opowiadanie - ważną czynnością jest dokonanie wyboru (elementów składowych) w celu ich teatralnego przetworzenia. Całość zyskuje na scenie swą teatralną konkretyzację; przede wszystkim zaś adaptacja jest swoistą i zazwyczaj jednorazową interpretacją (Puchalska 16-22, 251-260).

Amerykańska badaczka problemu, Linda Hutcheon, przedstawia adaptacje operowe i musicalowe jako „umuzycznienie” dzieła wyłącznie literackiego za pomocą orkiestry, która zaczyna pełnić rolę narratora: zastępuje go w metaforyczny sposób, dodając emocjonalne tło do toczącej się na scenie akcji i spajając opowiadaną historię w całość (Hutcheon 12 i nast.).

Z kolei piszący o przekładzie intersemiotycznym polscy badacze zwracają uwagę na odczytywanie adaptacji poprzez werbocentryzm literatury i wielokodowość sztuki teatralnej (w tym opery) (zob. Wysłouch 60-65), a także na możliwość dokonywania samego procesu adaptowania poprzez zastosowanie podstawowych działań potrzebnych przy tworzeniu figur retorycznych, takich jak adjekcja, detrakcja i transmutacja (Ziomek 355-390).

Większość uwag teoretyków adaptacji i przekładu intersemiotycznego dotyczy literackich dzieł dramatycznych lub udramatyzowanych utworów narracyjnych, bogatych w rozmowy bohaterów. Przeróbka na scenę bardzo obszernego dzieła epickiego, w dodatku niemal pozbawionego dialogów, nieczęsto bywa brana na warsztat przez adaptatora i - co za tym idzie - rzadko też staje się przedmiotem rozważań krytycznych.

Warto wobec tego przyjrzeć się literackiemu źródłu, tak skrótowo i bezceremonialnie potraktowanemu przez francuskich librecistów Offenbacha; może w jego strukturze i rodzajowej specyfice znajdzie się odpowiedź na pytanie o powód (sekret?) nieprzekładalności? Życie i zadziwiające przypadki Robinsona Crusoe, marynarza z Yorku (1719 rok) to dzieło ważne dla całej kultury europejskiej z wielu względów. Zrazu odbierana jako powieść przygodowa, z czasem stała się oświeceniowym nowatorskim wykładem na temat kształtowania człowieka, o czym pisał z wielką mocą Jean Jacques Rousseau w traktacie Emil (1762). Przy czym powieść Defoe nie ma charakteru wyraźnie czy nawet natrętnie dydaktycznego, wyrażonego wprost: jest raczej rodzajem dziennika z elementami pamiętnika i relacji unaoczniającej, jednocześnie zaś - wspomnieniem i opisem życia, a szczególnie w tomie pierwszym - opisem długotrwałego pobytu głównego bohatera na bezludnej wyspie. Robinson pisze, co go spotkało i jak sobie poradził, i jeśli stosuje parenezę, to tylko wobec samego siebie. 
Defoe dzięki swej nowoczesnej metodzie pisarskiej i bezpośrednim formom języka niezmiernie rozwinął nie tylko tak zwany travel book, ale i powieść-pamiętnik, wzbogacił europejską epikę o nowe rozwiązania narracyjne, przede wszystkim zaś stworzył postać bohatera-narratora, ukazanego bezpośrednio podczas procesu pisania, wiarygodnego uczestnika i świadka opisywanych wydarzeń w jednej osobie. Zadziwiające jest to, że obszerna opowieść snuta przez bohatera ani przez chwilę nie nuży, a relacje o jego kolejnych „pracach i dniach” czyta się jak najbardziej ekscytującą kryminalną intrygę. „Ciekawe, co będzie dalej?” - myśli czytelnik często, bo nie: „ciekawe, jak to się skończy?” - narrator już na wstępie wysłał odbiorcy sygnał, że fakty i wydarzenia relacjonuje $z$ bezpiecznej perspektywy czasowej i przestrzennej: po trzydziestu niemal latach, w domu w Anglii, z dostatecznym zapasem papieru i inkaustu, których tak bardzo brakowało mu na wyspie. Może teraz pisać, pisać, pisać...

$\mathrm{Na}$ czym polega szczególna atrakcyjność prozy Defoe? Bynajmniej nie na ułatwianiu procesu przyswajania tekstu. Virginia Woolf w eseju Jak czytać książki zaznaczyła z mocą:

Czytanie powieści to sztuka złożona i trudna. Trzeba być obdarzonym nie tylko wielką subtelnością percepcji, ale także śmiałością wyobraźni, żeby skorzystać ze wszystkiego, co powieściopisarz - wielki artysta ofiarowuje czytelnikom (Woolf 35-36).

Defoe, swojego poprzednika na niwie literatury angielskiej, pisarka stawia na czele panteonu wielkich. Tworzył on bowiem dla „zwykłego czytelnika, niezdeprawowanego literackimi uprzedzeniami” (to określenie Woolf zaczerpnęła od Samuela Johnsona), i to „zwykłemu czytelnikowi” dostarczał najwięcej radości (Woolf 31). Jedną z najbardziej ujmujących cech pisarstwa Defoe jest, jej zdaniem, jasność narracyjnego wykładu:

Tutaj, w Robinsonie Crusoe kroczymy prostą, szeroką drogą; jedna rzecz następuje po drugiej; fakty i ich porządek wystarczają. [...] Otwarte przestrzenie i przygoda są dla Defoe wszystkim [...]. Bohater wchodzi w związki nie z innymi ludźmi, bo ich zwyczajnie nie ma, ale „z Naturą i losem"; autor zaś - bo taki przyjął punkt widzenia - przedstawia fakty (Woolf 35, 63, podkr. J.M.).

W tym nieskomplikowaniu zastosowanych środków - jak się domyślamy, wynika to $\mathrm{z}$ autentyczności wielu z opisywanych przeżyć (Defoe przyznawał, że Przypadki Robinsona Crusoe to alegoria jego własnego życia) -Woolf upatruje 
uniwersalności utworu, wielkości, która polega na niezwykłym połączeniu arcydzielności z przystępnością. Robinson sam jest tak wiarygodnym i zajmującym uwagę narratorem, bo w pierwszej osobie liczby pojedynczej opowiada swoje dzieje; jednocześnie panuje nad całością przekazu, na przykład pewne fragmenty relacji z różnych przygód zapowiada, niektóre opisuje, inne pomija, oświetla swoje aktualne położenie naiwnymi sądami młodzieńca, jak i wiedzą doświadczonego przez los, błądzącego i - co najważniejsze - gotowego przyznać się do swoich błędów, strudzonego, bardzo już dojrzałego człowieka:

Nieraz zastanawiałem się nad tym, jak pełne sprzeczności i nierozumne jest ludzkie usposobienie, szczególnie u młodych, którzy zboczywszy raz z dobrej drogi bardziej wstydzą się skruchy niż przewinienia. Nie zawstydzają ich uczynki, które słusznie pozyskały im miano szaleńców, ale powrót na drogę cnoty, co właśnie zjednałoby im szacunek rozumnych i poczciwych ludzi (Defoe 17).

Niewiele jest w powieści uogólnień. Narrator-bohater jeśli prezentuje postawę krytyczną, to przede wszystkim wobec własnych czynów i wyborów:

Ale niestety! Nie był to mój pierwszy błąd ani ostatni, wszystko bowiem zawsze robiłem na opak. Nie było innej rady jak iść naprzód. Zabrałem się do zajęcia tak sprzecznego ze sposobem i rodzajem życia, jakie mnie pociągało, dla którego opuściłem dom ojca mego i odrzuciłem wszystkie jego dobre rady i wskazania. Znalazłem się właśnie ponad stopniem najniższego bytowania w owym średnim stanie, który mój ojciec niegdyś mi zalecał i który mogłem osiągnąć w domu, u swoich, nie włócząc się po świecie w trudach i kłopotach (Defoe 31).

Ale żem był z urodzenia niszczycielem własnego szczęścia, nie potrafiłem powstrzymać się od pokusy, jak nie umiałem pohamować mych pierwszych zapędów włóczęgostwa, nie bacząc na dobre rady ojca (Defoe 35).

Defoe w mistrzowski sposób realizuje zasady opowieści unaoczniającej, i - nie tracąc nic z pisarskiego zamiaru odtworzenia refleksyjnej natury bohatera - osiąga efekt utożsamienia czytelnika z narratorem.

[...] W jednej chwili wszyscy znaleźliśmy się pod wodą. Niepodobna opisać zamętu myśli, jakiego wówczas doznałem. Wprawdzie pływałem 
doskonale, jednakże nie mogłem wydobyć się z przemocy fal bodaj dla złapania oddechu. Na koniec jedna $\mathrm{z}$ fal porwała mnie, a raczej uniosła ku wybrzeżu, tam rozbiwszy się odeszła z powrotem i postawiła mnie na niemal suchym lądzie. [...] Usiłowałem biec dalej, zanim następna fala zmiecie mnie [...]; ujrzałem za sobą zwały wodne tak potężne jak góry, a zaciekłe jak wróg, z którym już nie stało sił walczyć. Mogłem tylko zaprzeć w sobie dech i utrzymywać się, ile tylko można, nad wodą, kierując się wciąż ku wybrzeżu (Defoe 38).

Jakiegoż mistrzostwa pióra wymaga, przy opisie tonącego raz po raz i wydostającego się uparcie na brzeg, przeprowadzenie jakby mimochodem alegorezy człowieczego losu, opisanie poszczególnego bytu i ziemskiego przeznaczenia całej rodziny ludzkiej. Defoe to potrafił.

[...] z wielką ulgą wygramoliłem się na sterczące wzniesienie brzegu i siadłem na trawie, wolny od niebezpieczeństwa i z dala od zasięgu wody. Byłem więc już wreszcie na lądzie, cały i bezpieczny. Podniosłem oczy w górę i dziękowałem Bogu za wybawienie mnie z iście beznadziejnego położenia. Niepodobna wyrazić uczucia zachwytu człowieka, który, rzec można, został niejako z grobu uratowany (Defoe 39).

Robinson panuje nad sytuacją zarówno w świecie przedstawionym, jako bohater, jak i w konsekwentnym kreowaniu swojego wizerunku: świadka uczestnika - narratora:

Gdy już spędziłem tak jakich dziesięć czy dwanaście dni, przyszło mi na myśl, że wskutek braku książek, pióra i atramentu mogę zatracić rachubę czasu i nie odróżniać dni świątecznych od powszednich. Ażeby temu zapobiec, wyciąłem nożem na graniastym słupie w kształcie krzyża, wbitym w ziemię na miejscu pierwszego lądowania, następujący napis: „Tutaj wylądowałem 30 września 1659”. Na bokach tego słupa nacinałem codziennie jeden karb, a co siódme nacięcie było dwa razy dłuższe od sześciu poprzednich, a pierwszy dzień każdego miesiąca dwa razy tak długi jak nacięcie na dni świąteczne. W ten sposób prowadziłem kalendarz, czyli tygodniową, miesięczną a w końcu i roczną rachubę czasu (Defoe 51-52).

Gdym już się tak dobrze urządził, począłem prowadzić dziennik zajęć codziennych (Defoe 55). 
Największym twórczym sukcesem literackim Daniela Defoe jest - poprzez zastosowanie narracji utożsamiającej i wprowadzenie pobudzającego wyobraźnię odbiorcy opisu (czynności, zachowań, doświadczeń, uczuć) - dostarczenie czytelnikowi niespotykanej dotąd satysfakcji lekturowej.

Oto człowiek, który znalazł się w sytuacji granicznej - samotny, pozbawiony środków do życia i przeżycia: jedzenia, domu, odzienia, sprzętów - radzi sobie i racjonalnie, i praktycznie. Nic nie dzieje się „samo przez się”, za pomocą nadzwyczajnych zbiegów okoliczności, pomocy innych ludzi czy ingerencji sił nadprzyrodzonych. Wszystkie trudności Robinson pokonuje samodzielnie dzięki wiedzy, umiejętnościom manualnym i zwykłej pracowitości. „Zetknięcie z Naturą" wyzwala w bohaterze energię, siły a przede wszystkim chęć przeżycia. Metodycznie poznaje wyspę, rozpoznaje swoje na niej możliwości, wciąż pamięta o konieczności wypatrywania ratunku od przepływających jednostek. Jest przezorny i silny, bywa także naiwny i słaby, ale doświadczenie, które zyskuje, nigdy nie idzie w zapomnienie, przeciwnie - wzbogaca go i ubezpiecza od złej przygody.

Uratowane $\mathrm{z}$ wraku statku narzędzia pomagają mu w tym wydatnie, pomaga też Biblia (Robinson ma jej aż trzy egzemplarze) i modlitwa - stanowią moralne wsparcie, pociechę, uzasadnienie dla witalizmu i pracy. Robinson modli się, ale wszystko i tak robi sam; zdaje się na boską opiekę, ale nie na boską interwencję. Na przykład gdy jest chory, modli się intensywnie o zdrowie, a w miarę możności próbuje wydobyć się z opresji praktycznymi sposobami (zob. szczególnie Defoe 72-75).

Od obawy przed zgubą ratuje go aktywność, od poczucia beznadziejności modlitewna kontemplacja. Robinson jest myślący, poważny, a w trakcie pobytu na wyspie staje się też dojrzały: zaczyna odróżniać dobro od zła, rozumieć, że to nie pieniądze są ważne, bo na wyspie na nic się nie zdadzą; dochodzi też do najważniejszego wniosku - że życie jest wartością daną tylko raz i że nie wolno go marnować. Terapeutyczna, by tak rzec, moc powieści (szczególnie gdy spojrzymy na sporządzoną przez Robinsona tabelkę „Wszystkie dobre i złe wydarzenia”, to współczesne rozpoznanie się potwierdza) jest jej ogromną wartością. Aktualnie atrakcyjnym komentarzem wydawniczym do książki mogłaby być formuła, że z tego oto tomu dowiemy się, jak przeżyć w ekstremalnych warunkach i nie zwariować, jak pracować nad sobą, dbać o swój rozwój osobisty, jak skutecznie odbudować poczucie własnej wartości... Defoe-terapeuta mówi nam o tym swym opasłym tomem zupełnie jasno, potwierdzając wiarygodność przekazu pokorą wobec losu i chęcią podzielenia się wyraźnie własnym doświadczeniem³.

3 Oczywiście, zarysowany przy okazji przygód i doświadczeń Robinsona jego stosunek do tubylczych mieszkańców okolicznych wysp i do Piętaszka jest dla nas absolutnie 
Zaprezentowane tu przypomnienie libretta opery Robinson Crusoe oraz krótkie opisanie walorów literackich powieści o tym samym tytule ukazują nam dwa zupełnie różne, nie tylko rodzajowo, dzieła; utwory, pochodzące ze światów, kierujących się odmiennymi systemami wartości i różnymi założeniami nadawczymi (edukacyjnymi). Komediowe ujęcie przygód Robinsona w wersji sceniczno-muzycznej czyni zeń bohatera popularnego, ale niekoniecznie tożsamego z tym, którego znamy z powieści Daniela Defoe. Literacki Robinson nigdy nie śpiewał, ba - nawet nie tęsknił w swej samotni za muzyką; za rozrywkę codzienną i odświętną miał fajkę, pisanie dziennika i lekturę Biblii. Jako bohater epicki jest „nie muzyczny”, a zgodnie ze znaną typologią przeważa w nim skłonność do mnożenia słów, czyli do metonimii; nie czuje metafory, której żywiołem jest liryka i asemantyczna muzyka. Jest też poważny i nieskory do śmiechu ${ }^{4}$.

Oryginalność i wyjątkowość powieściowego przekazu płynącego z historii życia Robinsona polega na ukazaniu wyrazistego, silnego choć niedysponującego nadprzyrodzonymi mocami bohatera, definiującego na nowo swoje człowieczeństwo w zetknięciu z Naturą. Sprowadzanie tej opowieści do kilku zabawnych sytuacji i przygód na egzotycznej wyspie z dzikimi tubylcami i dopisanym banalnym wątkiem romansowym nie przydaje jej walorów teatralnych, a wręcz odziera ją z artystycznej atrakcyjności.

Powstałe wcześniej (tj. przed Robinsonem Crusoe) popularne dzieła Offenbacha były w istocie komicznymi parafrazami wzniosłych, pradawnych i poważnych opowieści o bogach. Wysoki i patetyczny styl przekazów mitycznych został w nich zastąpiony przez styl niski, często wręcz dosadny, co w konfrontacji z rangą pełnionych przez boskich bohaterów funkcji, dzięki sile kontrastu, dawało efekt żartobliwy i satyryczny. Taką parafrazę badacz retoryki nazwał „zstępującą” i klasyfikował jako trawestację (Ziomek 78 i nast.). I tak - Piękna Helena i Orfeusz w piekle byłyby znakomitymi parafrazami komicznymi, czyli trawestacjami starożytnych mitów.

W przypadku opery o Robinsonie Crusoe z czasem zatarł się kontekst: pierwotny, zamierzony adresat (cel) satyry (poważna opera, nadęty Wagner, ozdobna egzotyka), a pozostała tylko wartka akcja spleciona $z$ wątkiem melodramatycznym. Te elementy budowy dzieła okazały się niewystarczające, by

nie do przyjęcia. Jeśli jednak zdjąć z bohatera odpowiedzialność za wszystkie podboje kolonialne świata, zostanie nam godna uwagi i interesująca z psychologicznego punktu widzenia krzepiąca postać ukazana w pozytywnym, także i dziś, świetle oraz w chęci pracy nad ciągłym własnym rozwojem duchowym.

4 Rzadki moment, w którym narrator wspomina o wesołości i śmiechu, to... zabicie niedźwiedzia przez Piętaszka! Ma to miejsce już po przybyciu bohaterów do Europy. Zaiste - komizm dziwnej próby, na szczęście sprzed 300 lat (zob. Defoe 215-218). 
ująć publiczność - zapewne też dlatego, że epicki pierwowzór literacki budził w odbiorcach zgoła inne uczucia niż starożytne greckie opowieści o mściwych i zazdrosnych mieszkańcach Olimpu.

Bardzo trudno znaleźć informacje na temat opery Offenbacha Robinson Crusoe. Nie wymieniają jej popularne przewodniki ogólne, niewiele piszą o niej wyspecjalizowane opracowania historyczne. Istnieje tylko jedno nagranie płytowe, wydane w serii Opera Rara (czyli rzadka opera) w 1980 rokus .

Jest jakiś powód tego zapomnienia. I, jak sądzę, wynika on z pogwałcenia natury dzieła przez librecistów i kompozytora, którzy nie rozpoznali trafnie klasy i dyspozycji adaptacyjnych powieści Defoe. Zapomnieli też, że nie każdą opowieść można potraktować jako materiał na lekką, muzyczną komedię.

Przygody Robinsona Crusoe, najczęściej wydawana - w pełnej wersji i w skrótach - oraz najczęściej tłumaczona powieść świata zyskała uznanie „Zwykłych czytelników”, tych, którzy różnią się, zdaniem Johnsona i Woolf, od krytyków i uczonych szczerością aprobaty wobec literatury. To dla nich pisał Defoe. Opera komiczna Offenbacha na podstawie powieści zrobiła i jednorazową, i „trwałą" klapę, bo zbanalizowała wyjątkową historię o wybitnym i jednocześnie pospolitym człowieku. O jej popadnięciu w niebyt zadecydowali „Zwykli widzowie”.

\section{| Bibliografia}

Crichton, Ronald. "Robinson Crusoe". The Musical Times, May (1982). S. 340.

Dean, Winton. "Robinson Crusoe". The Musical Times, May (1973). S. 508-509.

Defoe, Daniel. Przypadki Robinsona Crusoe. Przeł. Józef Birkenmajer. Warszawa:

Państwowy Instytut Wydawniczy, 1986.

Faris, Alexander. Jacques Offenbach. Londyn: Faber \& Faber, 1980.

Gier, Albert. Das Libretto. Teorie und Geschichte einer musikoliterarischen Gattung. Darmstadt: Wissenschaftliche Buchgesellschaft, 1998.

Hutcheon, Linda. A Theory of Adaptation. With Siobhan O'Flynn. New York: Routledge, 2013.

Kamiński, Piotr. Tysiąc i jedna opera. T. 1-2. Warszawa: Polskie Wydawnictwo Muzyczne, 2008.

5 Brak wzmianek o operowym Robinsonie na przykład w Kronice opery i w tomie: Opera. Kompozytorzy, dzieła, wykonawcy (oprac. A. Batta, red. S. Neef). Istotne informacje zawiera tylko Tysią i jedna opera Piotra Kamińskiego. 
Kracauer, Siegfried. Jacques Offenbach i Paryż jego czasów. Przeł. Andrzej Sąpoliński. Warszawa: Państwowy Instytut Wydawniczy, 1992.

Kronika opery. Oprac. zespół. Przeł. Jolanta M. Michasiewicz. Warszawa: Wydawnictwo Kronika, 1993.

Lamb, Andrew. "Robinson Crusoe". Grove Music online. Oxford University Press. Web. 30.09.2019. <https://doi.org/10.1093/gmo/9781561592630.article. Ooo7686>

Maleszyńska, Joanna. „Biblijna przypowieść o synu marnotrawnym i jej literackie transpozycje”. Miejsca wspólne. Szkice o komunikacji literackiej i artystycznej. Red. E. Balcerzan, S. Wysłouch. Warszawa: Państwowe Wydawnictwo Naukowe, 1985. S. 221-239.

Nowicka, Elżbieta. Zapisane w operze. Studia z historii i estetyki opery. Poznań: Wydawnictwo Poznańskie, 2012.

Opera. Eyewitness Companions. Oprac. A. Riding, L. Dunton-Downer. New York: Dorling Kindersley, 2006.

Opera. Kompozytorzy, dzieła, wykonawcy. Oprac. A. Batta. Red. S. Neef. Przeł. zespół. Kraków: Konemann, 2003.

Puchalska, Iwona. Sztuka adaptacji. Literatura romantyczna $w$ operze dziewiętnastowiecznej. Kraków: Universitas, 2004.

Ruszała, Jadwiga. Robinsonada w literaturze polskiej: teoria, typologia, bohater, natura. Słupsk: Pomorska Akademia Pedagogiczna, 2000.

Traubner, Richard. Operetta: A Theatrical History. London: Routledge, 2016.

Woolf, Virginia. Eseje wybrane. Wybór i oprac. R. Sendyka. Przeł. Magda Heydel. Kraków: Wydawnictwo Karakter, 2018.

Wysłouch, Seweryna. „Werbocentryzm - uzurpacje i ograniczenia”. Literatura i semiotyka. Warszawa: Wydawnictwo Naukowe PwN, 2001. S. 53-64.

Ziomek, Jerzy. „Przekład - rozumienie - interpretacja. Parodia jako problem retoryki”. Powinowactwa literatury. Warszawa: Wydawnictwo Naukowe PwN, 1980. S. 159-200.

\section{| Abstrakt}

JoAnNa MaleszyńsKa

Robinsonada na scenie albo dzieje nieudanej adaptacji

Artykuł Robinson na scenie czyli dzieje nieudanej adaptacji dotyczy opery komicznej Robinson Crusoe Jacquesa Offenbacha, której libretto powstało w oparciu o fabułę wielkiej powieści Daniela Defoe. Adaptacja, dokonana przez fran- 
cuskich librecistów w drugiej połowie xıx wieku, daleko odbiegła od epickiego pierwowzoru i z powieści będącej epickim hymnem na cześć ludzkiej zaradności i siły przetrwania uczyniła błahą komedię z banalną akcją i bez głębszego przesłania. Porównanie dwóch różnych gatunkowo tekstów o tym samym bohaterze przynosi wniosek o organicznej nieprzekładalności monumentalnej powieści, szczególnie na komedię, przeznaczoną na scenę muzyczną.

Słowa kluczowe: opera, powieść, adaptacja, libretto, bohater

\section{| Abstract}

\section{JoAnNA MALESZYŃSKA}

\section{A Robinsonade or a Story of a Failed Adaptation}

The article discusses Jacques Offenbach's operetta Robinson Crusoe, whose libretto is based on the great 1719 novel by Daniel Defoe by the same title. The adaptation by French librettists in the late 19th century is a far cry from the original narrative. The novel, an epic hymn to human resourcefulness and resilience, became a light comedy with a trite story line and without a deeper message. The analysis of two formally very different texts with the same protagonist brings about a conclusion of an innate impossibility of translating a grand novel to a comedy stage.

Keywords: opera, novel, adaptation, protagonist, libretto

\section{| Nota o autorce}

Joanna Maleszyńska - prof. UAM, dr hab. Pracuje w Zakładzie Poetyki i Krytyki Literackiej IFP UAM oraz w Centrum Badań nad Teatrem Muzycznym UAM. Zajmuje się badaniem form literacko-muzycznych, reprezentowanych przez gatunki wielkie i małe - operę, musical, pieśń i piosenkę, historią liryki xx wieku, twórczością piosenkową i kabaretową czasu wojny i okupacji, specyfiką kultury popularnej. Autorka książki Apologia piosenki. Studia z historii gatunku (Poznań 2013).

E-mail: jwmaleszynska@yahoo.com 